\title{
BODY HEIGHT AS A SOCIAL SIGNAL
}

\author{
Michael Hermanussen $^{1}$, Christiane Scheffler ${ }^{2}$ \\ ${ }^{1}$ University of Kiel, Kiel, Germany \\ ${ }^{2}$ Institute of Biochemistry and Biology, University of Potsdam, Potsdam, Germany
}

\begin{abstract}
Body height has a signaling function among social mammals. Humans also perceive physical size as a signal and tend to associate stature and status. Taller men are perceived as more competent and authoritative. Studies in wild Kalahari male meerkats (Suricata suricatta) suggest that dominance itself can be a stimulus for growth allowing for competitive growth and strategic growth adjustments. Assuming that similar mechanisms on the control of growth are also relevant for humans, our understanding of the shortness of many Third World populations has to be revised. Short stature may no longer be exclusively understood as an expression of poverty, chronic malnutrition and poor health but as an expression of persistent feelings of inferiority and patronization in the face of the global spread and dominance of Western life and moral codes.
\end{abstract}

Keywords: child growth; social role; dominance; community effect on height; competitive growth; strategic growth adjustment

When considering basic social interaction patterns, it is often forgotten that people are social mammals. Competition for resources and struggle for reproductive success are universal and require adaptation strategies to the given physical and social environment. Like other social mammals, people also join together in groups, experience group membership, are "at eye level" with other group members but are also excluded and "pull their heads in" - "make themselves small" - in order to survive the competition with the greatest possible success. 
It has long been known that body height has a signalling function among social mammals [8]. This also applies to humans. Humans are able to perceive physical size as a signal of social dominance. The greater influence of perceived taller humans in a negotiation task has been described by Huang et al. [15]. Taller men are perceived as more competent and authoritative [15, 17, 8]. Also, children are able to recognize cues that predict dominance [22]. They recognize physical size of the individual members of the group and numerical alliances.

\section{DOMINANCE AND BODY HEIGHT}

Recent studies of wild Kalahari meercats (Suricata suricatta) suggest that social dominance itself can be a strong growth impulse. Meerkats that "acquire dominant status, show a secondary period of accelerated growth whose magnitude increases if the difference between their own weight and that of the heaviest subordinate of the same sex in their group is small" [16]. It is the relative, not the absolute size that serves as the signal for "individuals (to) adjust their growth to the size of their closest competitor." If, for example, the growth of individual animals that are low in the group hierarchy is stimulated beyond the usual level by targeted supplementary feeding, hierarchically higher group members may feel threatened. This threat can increase the growth rate. Meerkats are able to adapt individual growth rates competitively to social conditions. They grow "strategically". Huchard et al. showed that the abolition of reproductive suppression and the reorientation of life history strategies on the occasion of the acquisition of a dominant position is accompanied by corresponding hormonal changes, with higher estradiol and progesterone levels in females and cortisol levels in both sexes. In other social species, subordination also leads to inhibition or dominance to stimulation of growth.

Sapolsky \& Spencer [25] investigated the relationship between social status and IGF-1 (insulin-like growth factor 1) in baboons and observed that social subordination was associated with suppression of IGF-1 concentration. Bartos and colleagues [2] showed in pudus, a South American deer species, that, from September to November (the second part of the antler growth period), the IGF-1 levels of dominant males were significantly higher than those of subordinate males.

Body height and IGF-1 are related. But relations between social status and IGF-1 have hardly been described in humans. Kumari et al. [20] investigated the association between social position, measured by paternal or own occupational class, and IGF-1. Low IGF-1 values were associated with lower social 
position. The association was valid for adults and was independent of the social position at birth.

The small number of endocrinological studies in individuals does not immediately reveal whether the principles of strategic growth adjustments also apply to humans, as already suggested by Huchard et al. [16]. However, extensive historical data suggests that strategic growth also plays a role in humans.

In contrast to meerkats who do not stop growing at the beginning of the reproductive age, humans are usually fully grown by the time when they start to achieve leading positions in society. As strategic adjustments of growth and body height cannot take place after adolescence, short adults who occupy important positions, thus, often tend to underline their social role by particular behaviour - everyone is familiar with the "little Napoleon" or "little man" syndrome.

In human adolescents, even the prospect of a later dominant social position seems to stimulate growth. Kings and members of the aristocracy have always grown taller than ordinary people. Height measurements of Carl's High School students from the late 18th century show that young aristocrats grew significantly taller than their non-aristocratic schoolmates - irrespective of diet, health and general living conditions. This is an interesting story.

Between 1763 and 1767, Duke Carl Eugen of Württemberg had a hunting lodge built near Stuttgart. His adjutant, Colonel von Seeger, suggested that he set up a school for children of military soldiers in the adjoining buildings of the palace. This soon developed into a military academy, the so-called Hohe Carlsschule where the young people were subjected to a strict but excellent education under the eyes of the sovereign. Many officers, civil servants and people from the state now sent their sons to this institution which gradually transformed into an elite educational institution. Social differences were not tolerated; the lessons lasted eight hours a day, including physical exercises as drill hours. The boys wore uniforms, were subject to military ceremonial, and lived in military barracks. In the beginning, there were no holidays at all, later only very short ones, so that the teachers and the pupils lived together practically constantly. The considerations, based on which the pupils were regularly measured in those days, are no longer comprehensible, but there are large sets of data on more than 1000 boys, some of which were measured over many years at very regular intervals [11].

Figure 1 shows body height of Carl's High School students from high aristocracy, low aristocracy and lower social classes. The young aristocrats were on average $10 \mathrm{~cm}$ taller than youths from the lower social classes, regardless of 
equal living conditions and traumatic separation from their parents' lifestyle. These young people only differed in their future prospects: some expected an aristocratic, i.e. dominant, social life, the others subordination.
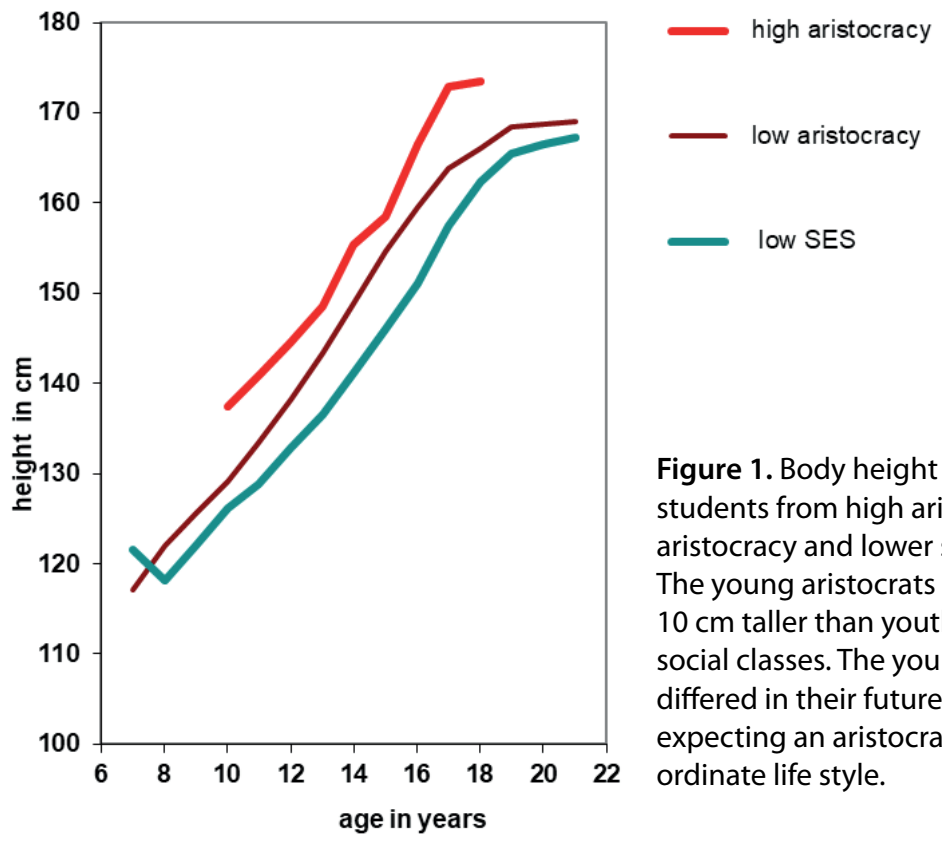

Figure 1. Body height of Carl school students from high aristocracy, lower aristocracy and lower social classes. The young aristocrats were on average $10 \mathrm{~cm}$ taller than youths from the lower social classes. The young people only differed in their future prospects, rather expecting an aristocratic, or a more subordinate life style.

Social differences in body height have long been known. Schlesinger wrote explicitly in 1925 [28]:

"The length curves of grammar school students and upper secondary school students are always several centimetres higher than those of elementary school students. The lowest curve is that of the children from the auxiliary school, most of whom originated from the lower proletariat. The growth advantage of the welldeveloped, well-situated boys from the grammar schools over their less well-off peers from the elementary school equals at least one year's growth rate in length, later in childhood and compared with less well-developed children, their growth rate may be double or even 2-3 years' growth rates. The difference in growth rate is not only great, it is also extraordinarily regular. The average lengths of groups of children of the same age and of the same developmental level allow a reliable classification of the social composition of those groups. In terms of weight gain, these differences are far from being so great and regular. Before puberty the differences correspond to half or three quarters of an annual growth rate." 
Numerous publications before, during and after the First World War underline that differences in body height between different classes are caused neither by differences in nutrition nor by differences in health $[12,13]$.

\section{COMMUNITY AND BODY HEIGHT}

Eveleth and Tanner [9] wrote that "humans differ in size". Children of tall parents tend to grow taller than children of short parents. There are tall populations - Dutch men have an average height of $184 \mathrm{~cm}$ and are currently considered the tallest [10] - and there are short populations, such as the people of Guatemala or Indonesia. For a long time, these observations have given rise to speculations about the genetics of body height. The literature is still full of estimates claiming that some $60 \%$ to $80 \%$ of body height variation is supposed to be genetic. This is not true. Around 1865, Dutch recruits were on average $163 \mathrm{~cm}$ tall, i.e. shorter than modern Indonesians. At present, modern Indonesian adolescents grow similarly to Hamburg Latin School students in 1879 [19]. The amazing increments in body height of Europeans did not start before the beginning of the $20^{\text {th }}$ century. The NCD Risk Factor Collaboration [23] describes a worldwide body height trend of up to plus $20 \mathrm{~cm}$ in individual populations in the last hundred years. The relatively slow generational sequence of human societies with its comparatively small number of descendants and thus relatively little change in the genome of a society suggests that the body height trends in the course of only four to five generations can hardly be explained by genetics. Using a genome-wide association study, Tyrrell et al. [30] described that the 396 genetic variants studied by them explained only $12.3 \%$ of the variance in adult size.

In contrast to the high variability of body height between populations, the variability of body height within populations appears rather small. More than 10 years ago, Christakis and Fowler [7] described the spread of obesity in social networks and highlighted the similarity in weight among people who know each other: you are always as fat as your friends. This also applies to body height. Studies of Swiss and Norwegian military conscripts showed that height is related within geographically neighbouring districts [3,4]. People whose places of residence are close to each other are more similar in height than people who do not or rarely meet. We call this "community effect in body height" [1]. The community effect in body height describes the "effect of social interaction within a group on the growth and body height of its members". The physiology underlying this phenomenon is unknown, but the corresponding demo- 
graphic statistics are impressive. Figure 2 shows the distribution of body height of Swiss (Schaffhausen) conscripts of the late $19^{\text {th }}$ and late $20^{\text {th }}$ century. The average height of this population has increased by almost $15 \mathrm{~cm}$ : whereas 100 years ago, nobody was tall - only single individuals grew taller than $182 \mathrm{~cm}-$ today, hardly anybody stays below $165 \mathrm{~cm}$, i.e. the median male size 100 years ago [14].

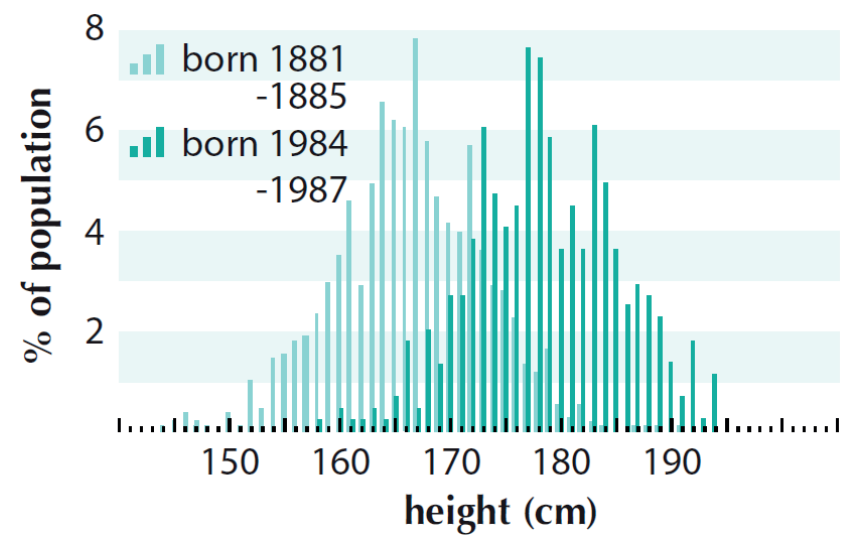

Figure 2. Distribution of body height of Swiss (Schaffhausen) conscripts of the late $19^{\text {th }}$ and late $20^{\text {th }}$ century. Average height of this population has increased by almost $15 \mathrm{~cm}$ (Hermanussen 2013, reprinted with kind permission of Schweizerbart).

Body height adjustments are not necessarily slow phenomena that take place during long historical periods. Children of migrants and adolescents with lower social status adjust in height to the average body height of their new reference population already within the first generation [6]. Figure 3 shows the "community effect in body height" among children of Guatemalan parents who lived in Guatemala and children who migrated to the USA. Migrant children had grown one and a half to two standard deviations (about 8-12 cm depending on age) taller than their nephews and cousins who had stayed in Guatemala. Spier [29] described the adaptation of migrant body height to the height of the new peer-group some 90 years ago in Japanese people who grew up in the USA. Spier found no explanation for this phenomenon, particularly, no evidence of dietary influence. 


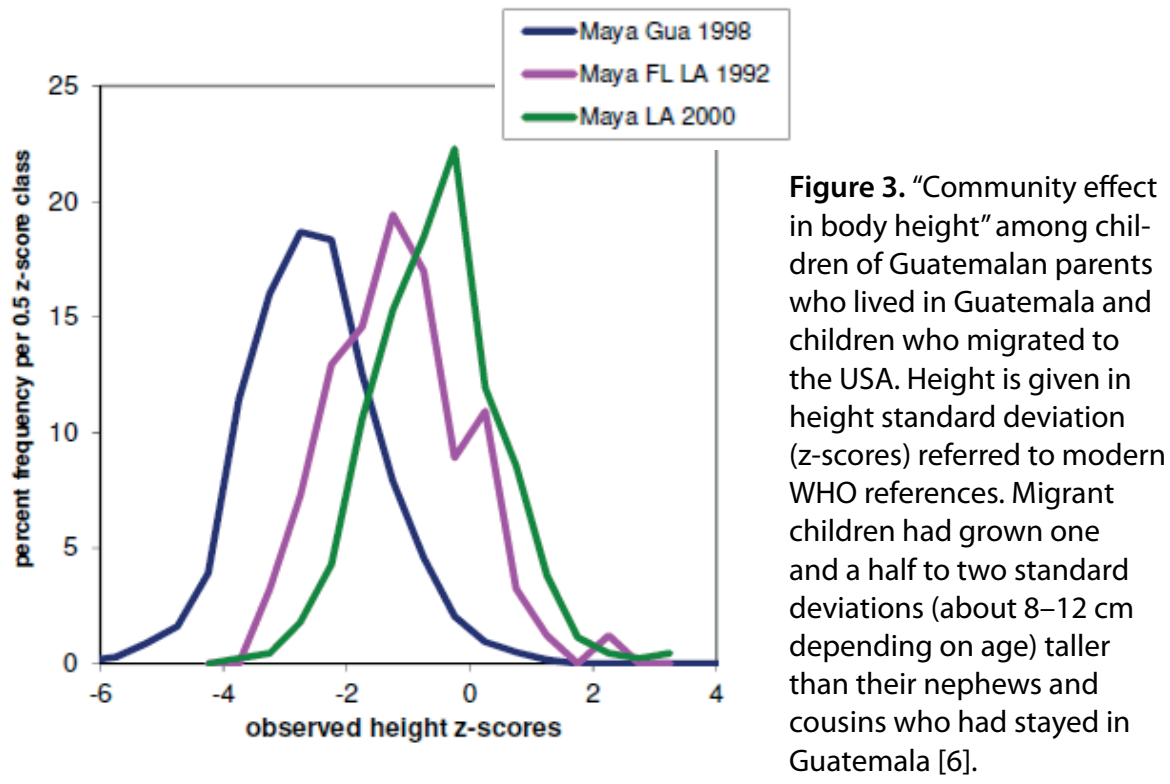

\section{BODY HEIGHT AND NUTRITION}

Apart from the belief in genetic influences, nutrition has also been assigned an important role in the regulation of growth. Lartey [21] writes: "There is increasing agreement among the nutrition community about the use of length/ height-for-age as the indicator to monitor the long-term impact of chronic nutritional deficiencies." Lartey calls stunting (stunting is defined as growth and developmental disorder experienced by children through poor nutrition, repeated infections and inadequate psychosocial stimulation) an "indicator of linear growth failure", with "both long- and short-term consequences affecting growth and development and adult work potential." Prendergast and Humphrey identified a "stunting syndrome" in developing countries in 2014 [24]. And Black et al. [5] estimated that 165 million children under the age of 5 are chronically malnourished. Children with a z-value for body height below -2 , are by definition regarded as "stunted", i.e. malnourished. Z-values are statistical measures. They indicate the position of a measured value within its distribution using the standard deviation. If a person's body height is 2 standard deviations below the population mean, he or she has a $\mathrm{z}$ - value of minus 2. Expressed as a percentage, a $\mathrm{z}$-value of -2 says that about two and a half percent of all people of the same age and sex are shorter, and $97.5 \%$ taller, than that person. 
The association between "stunting" and malnutrition has existed since the early 1970s [32], and since an international Nestle workshop in 1988 [33], the term stunting has become a synonym for malnutrition in scientific literature. This was not always the case. Already at the end of the $19^{\text {th }}$ century and - this makes these observations so remarkable - explicitly in view of the catastrophic nutritional situation of the German civilian population after World War I, German paediatricians in these days, wrote that "the longitudinal growth of the child is largely independent of the extent and type of nutrition..." [28]. Similar reports were made by other European paediatricians.

It is not always easy to assess the nutritional status of a child. Based on the vision that the thickness of the subcutaneous fat layer allows statements on the nutrition status, many publications have been published in recent years, but none of them has found a sustainable relationship between subcutaneous fat depot and body height. Figure 4 shows our own observations on body height (z-values according to WHO references) and triceps and subscapular skinfold thickness of healthy $1^{\text {st }}$ to $6^{\text {th }}$ grade schoolchildren of a rural (Soe) and an urban region (Kupang) in West Timor, Indonesia [27]. The inhabitants of this Indonesian island can be considered genetically similar; the everyday food is still quite traditional. Only in the few urban centres, fast food packed in small plastic bags is increasingly offered.

Skinfolds vs. Height (SDS WHO) - 6-12 year old children West-Timor
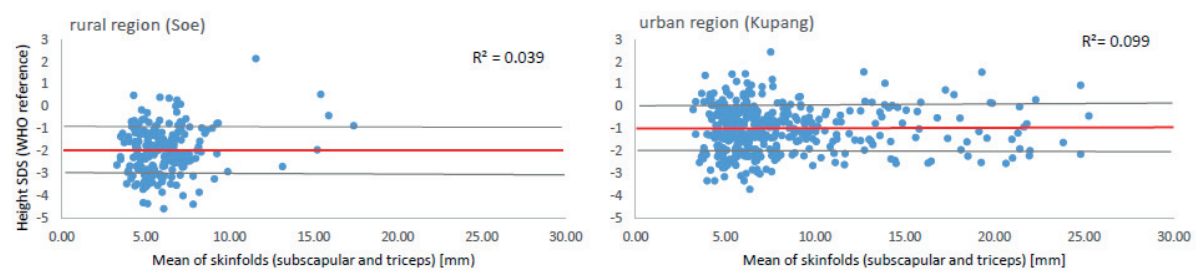

Figure 4. Body height ( $\mathrm{z}$-scores, WHO reference) and triceps and subscapular skinfold thickness of healthy $1^{\text {st }}$ to $6^{\text {th }}$ grade schoolchildren of a rural (Soe) and an urban region (Kupang) in West Timor/Indonesian. The red line indicates average $z$-scores. According to international definition, many children must be considered chronically malnourished, but with $R^{2}=0.04$, respectively, $R^{2}=0.1$, the figure lacks evidence of a relevant association between skinfold thickness and body height.

The rural children of Soe are very short; some $50 \%$ are stunted, with body height below minus 2 standard deviations (WHO reference), i.e. below the $2.5^{\text {th }}$ centile of the reference population. The children of Kupang are on average one standard deviation taller (approx. 5-6 cm), but the number of "stunted children" is still high. According to the international definition, these children 
must be considered chronically malnourished. Yet, the figure lacks evidence of a relevant association between skinfold thickness and body height. Children with little subcutaneous fat are not the shortest, and children with stronger fat tissue are not the tallest, neither in Soe nor in Kupang. The variation of the body height distribution is very similar in both populations [27].

Recent Indian data on "stunted children" of Sikkim, urban Kolkata [26] and the Ganges delta, similarly lack an association between height and nutritional status, as measured by the strength of skinfold thickness. Even the overweight children of these populations are short when referred to global references.

\section{THE DYNAMICS OF BODY HEIGHT TRENDS AS EXPRESSIONS OF SOCIAL AND POLITICAL CIRCUMSTANCES}

The association between body height and social strata, ethnic variability, and the remarkable trends in height during the last century on the one hand, and, on the other hand, the lack of convincing evidence of genetic and nutritional reasons for these patterns suggest alternative interpretations, especially in view of recent observations in social mammals.

As shown in recent studies in wild Kalahari male meerkats (Suricata suricatta), social dominance itself can be a strong growth impulse [16]. Meerkats are able to adopt individual growth rates and grow "strategically". Subordination may lead to growth inhibition and dominance to growth stimulation. These observations are new. If we assume that such social influences control growth, the capacity for competitive growth and the "strategic" adjustment of body height are also part of human growth regulation, such assumptions are radical. They do not only put many modern but also many historical observations on growth and data on adult height into a very different light. Think about subordinate meerkats that are growth stimulated by targeted supplementary feeding and start to threaten their hierarchically higher group members by growing faster than usual. Let us assume that like these social mammals, members of the lower social strata also start to "strategically" adjust in body height, when the political situation starts to promise social upgrade and a better future. In such a case, we must expect major dynamics in body height during these historic periods. In fact, this is the case.

In feudal systems where social rank is inherited, class affiliations are rigid, changes of class are rare. In fact, such systems lack dynamics in growth. Aristocrats are generally taller than the common people (Figure 1). Historic European military data show stability in body height up to the end of the $19^{\text {th }}$ century. The 
wave of social revolutions in the first half of the $19^{\text {th }}$ century was suppressed throughout Europe. Only in the Netherlands, the uprising in 1848 and 1849 led to democratic reforms. In Germany, the three-class right to vote persisted until the end of the imperial era. Figure 5 illustrates the changes in height of European conscripts, with significant height trends since the mid- $19^{\text {th }}$ century only in the Dutch [18].

After World War I, the political situation changed in most European countries, and so did growth and height. Schlesinger wrote in 1925 [28]:

... even when they (adolescents) are on a starvation diet, their size ruthlessly increases until their bodies have used up their last depots. One could even speak of a "parasitic" growth in length! Even during the years of severe hunger and the years of greatest unemployment, there was no, or only a very slight decrease in the average height of schoolchildren compared to the pre-war period.

And:

A completely new view on this issue was provided by Pfaundler who did not consider the short stature of the underprivileged children as the deviant, but on the contrary, rather discussed the excessive tallness of the children of the rich.

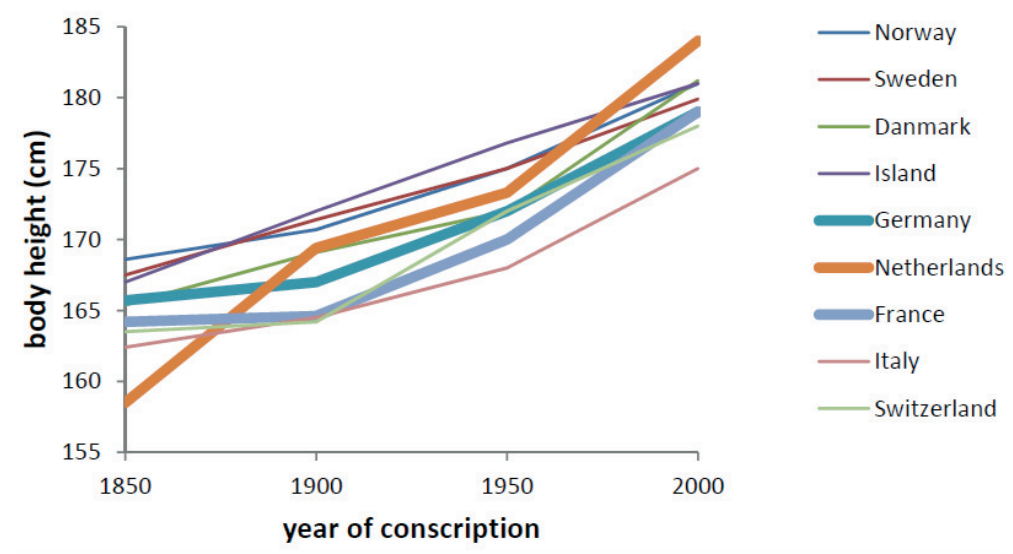

Figure 5. Body height of European conscripts, with significant height trends since the mid$19^{\text {th }}$ century only in the Dutch [18].

In other words, one the most famous physicians in those days, the AustrianGerman paediatrician Meinhard von Pfaundler (1872-1947), considered the highly stimulated growth of young people from wealthy families to be a pathology. 
Revolutions stir up hope. Hopes of social advancement and future dominance stimulate growth, and lead to increasing height of young lower-class people. When this increase in height is perceived as social challenge in the dominant strata, it may also cause upward trends in body height in these, and ultimately, may lead to a "strategic" upward spiral of body height growth in the entire population. Exactly this is found in the historic data. Periods of democratization, but also times of political turmoil, when social equality is promised, and vertical mobility and an ascent from the lower social strata becomes feasible, seem to be the motor of the exceptional body height increase observed in the European people since the end of the feudal period.

Considering this mechanism, we do no longer understand the shortness of many Third World populations as an expression of chronic malnutrition indeed, modern Cochrane Systematic Reviews [31] underline the insignificance of nutrition interventions in these countries ("Considering the current evidence base included, supplementary food effects are modest at best"). We understand the absence of secular height trends in these populations as an expression of persistent feelings of being inferior. South Africans name this inferiority complex and have coined the term "white privilege"; be it the consequence of colonial rule, be it lack of education, or an expression of perceived patronization in the face of the global spread and dominance of Western life and moral codes.

\section{REFERENCES}

1. Aßmann C., Hermanussen M. (2013). Modeling determinants of growth: evidence for a community-based target in height? Pediatr Res, 74, 1, 88-95. https://doi.org/10.1038/pr.2013.50

2. Bartos L., Reyes E., Schams D., Bubenik G., Lobos A. (1998). Rank dependent seasonal levels of IGF-1, cortisol and reproductive hormones in male pudu (Pudu puda). Comp Biochem Physiol A Mol Integr Physiol, 120, 2, 373-8. https://doi.org/10.1016/S1095-6433(98)10038-7

3. Bents D., Groth D., Satake T. (2018). The secular trend and network effects on height of male Japanese students from 1955 to 2015. Anthropol Anz, 74, 5, 423-429. https://doi.org/10.1127/anthranz/2018/0838

4. Bents D., Rybak A., Groth D. (2017). Spatial conscript body height correlation of Norwegian districts in the 19(th) century. Anthropol Anz, 74, 1, 65-69. https://doi.org/10.1127/anthranz/2017/0700

5. Black R.E., Victora C.G., Walker S.P., Bhutta Z.A., Christian P., de Onis M., Ezzati M., Grantham-McGregor S., Katz J., Martorell R., Uauy R.; Maternal and 
Child Nutrition Study Group (2013). Maternal and child undernutrition and overweight in low-income and middle-income countries. Lancet, 382, 9890, 427-451. https://doi.org/10.1016/S0140-6736(13)60937-X

6. Bogin B., Hermanussen M., Scheffler C. (2018). As tall as my peers - similarity in body height between migrants and hosts. Anthropol Anz, 74, 5, 365-376. https://doi.org/10.1127/anthranz/2018/0828

7. Christakis N.A., Fowler J.H. (2007). The spread of obesity in a large social network over 32 years. N Engl J Med, 357, 370-379

8. Cinnirella F., Winter J. (2009). Size matters! Body height and labor market discrimination: a cross-European analysis. - CESifo Working Paper Series, 2009, 1-29. https://doi.org/10.2139/ssrn.1466933

9. Eveleth P.B., Tanner J.M. (1990). Worldwide variation in human growth. 2nd ed. Cambridge: Cambridge University Press.

10. Fredriks A.M., Buuren S.V., Burgmeijer R.J.F., Meulmeester J.F., Beuker R.J., Brugman E., Roede M.J., Verloove-Vanhorick S.P., Wit J.M. (2000) Continuing positive secular growth change in the Netherlands 1955-1997. Ped Res, 47, 316-323. https://doi.org/10.1203/00006450-200003000-00006

11. Hartmann W. (1970). Beobachtungen zur Akzeleration des Längenwachstums in der zweiten Hälfte des 18. Jahrhunderts. „Carlsschule“. Dissertation. Frankfurt.

12. Hermanussen M., Bogin B., Scheffler C. (2018). Stunting, starvation and refeeding: a review of forgotten 19th and early 20th century literature. Acta Paediatr, 107, 7, 1166-1176. https://doi.org/10.1111/apa.14311

13. Hermanussen M., Bilogub M., Lindl A.C., Harper D., Mansukoski L., Scheffler C. (2018). Weight and height growth of malnourished school-age children during re-feeding. Three historic studies published shortly after World War I. Eur J Clin Nutr, 72, 1603-1619. https://doi.org/10.1038/s41430-018-0274-Z

14. Hermanussen, M. (ed) (2013). Studying Human Growth and Development. Stuttgart: Schweizerbart Science Publishers.

15. Huang W., Olson J.S., Olson G.M. (2002). Camera angle affects dominance in video-mediated communication. In: Proceedings of the Conference on Human Factors in Computing Systems. Association for Computing Machinery. New York, 716-717. https://doi.org/10.1145/506443.506562

16. Huchard E., English S., Bell M.B., Thavarajah N., Clutton-Brock T. (2016). Competitive growth in a cooperative mammal. Nature, 533, 7604, 532-534. https://doi.org/10.1038/nature17986

17. Judge T.A., Cable D.M. (2004). The effect of physical height on workplace success and income: preliminary test of a theoretical model. J Appl Psychol, 89, 428-441. https://doi.org/10.1037/0021-9010.89.3.428

18. Kenntner G. (1963). Die Veränderungen der Körpergröße des Menschen. Eine biogeographische Untersuchung. Dissertation. Karlsruhe. 
19. Kotelmann L. (1879). Die Körperverhältnisse der Gelehrtenschüler des Johanneums in Hamburg: Ein statistischer Beitrag zur Schulhygiene. Zeitschrift des Königlichen Preussischen statistischen Bureau's. Berlin.

20. Kumari M., Tabassum F., Clark C., Strachan D., Stansfeld S., Power C. (2008). Social differences in insulin-like growth factor-1: findings from a British birth cohort. Ann Epidemiol, 18, 8, 664-70. https://doi.org/10.1016/j.annepidem.2008.03.001

21. Lartey A. (2015). What would it take to prevent stunted growth in children in sub-Saharan Africa? Proc Nutr Soc, 74, 4, 449-53. https://doi.org/10.1017/S0029665115001688

22. Lourenco S.F., Bonny J.W., Schwartz B.L. (2016). Children and Adults Use Physical Size and Numerical Alliances in Third-Party Judgments of Dominance. Front Psychol, 6, 2050. https://doi.org/10.3389/fpsyg.2015.02050

23. NCD Risk Factor Collaboration (NCD-RisC) (2016). A century of trends in adult human height. Elife, pii: e13410. https://doi.org/10.7554/eLife.13410

24. Prendergast A.J., Humphrey J.H. (2014). The stunting syndrome in developing countries. Paediatr. Int Child Health, 34, 4, 250-265. https://doi.org/10.1179/2046905514Y.0000000158

25. Sapolsky R.M., Spencer E.M. (1997). Insulin-like growth factor I is suppressed in socially subordinate male baboons. Am J Physiol, 273, 4 Pt 2, R1346-51. https://doi.org/10.1152/ajpregu.1997.273.4.R1346

26. Scheffler C., Krützfeldt L.M., Dasgupta P., Hermanussen M. (2018). No association between fat tissue and height in 5019 children and adolescents, measured between 1982 and in 2011 in Kolkata/India. Anthropol Anz, 74, 5, 403-411. https://doi.org/10.1127/anthranz/2018/0827

27. Scheffler C., Hermanussen M., Bogin B., Liana D.S., Taolin F., Cempaka P.M.V.P., Irawan M., Ibbibah L.F., Mappapa N.K., Payong M.K.E., Homalessy A.V., Takalapeta A., Apriyanti S., Manoeroe M.G., Dupe F.R., Ratri R.R.K., Touw S.Y., K P.V., Murtani B.J., Nunuhitu R., Puspitasari R., Riandra I.K., Liwan A.S., Amandari P., Permatasari A.A.I., Julia M., Batubara J., Pulungan A. (2019). Stunting is not a synonym of malnutrition. Eur J Clin Nutr, May 29, doi: 10.1038/s41430-019-0439-4, ahead of print.

28. Schlesinger E. (1925). Das Wachstum des Kindes. Ergebnisse der inneren Medizin und Kinderheilkunde, 28, 456-579.

https://doi.org/10.1007/978-3-642-90637-4_9

29. Spier L. (1929). Growth of Japanese children born in America and in Japan. University of Washington Publication in Anthropology V3 No1.

30. Tyrrell J., Jones S.E., Beaumont R., Astley C.M., Lovell R., Yaghootkar H., Tuke M., Ruth K.S., Freathy R.M., Hirschhorn J.N., Wood A.R., Murray A., Weedon M.N., Frayling T.M. (2016). Height, body mass index, and socioeconomic status: mendelian randomisation study in UK Biobank. BMJ, 352, i582.

https://doi.org/10.1136/bmj.i582 
31. Visser J., McLachlan M.H., Maayan N., Garner P. (2018). Community-based supplementary feeding for food insecure, vulnerable and malnourished populations - an overview of systematic reviews. Cochrane Database Syst Rev, 11, CD010578. https://doi.org/10.1002/14651858.CD010578.pub2

32. Waterlow J.C. (1972). Classification and definition of protein-calorie malnutrition. BMJ, 3, 5826, 566-569. https://doi.org/10.1136/bmj.3.5826.566

33. Waterlow J.C. (1988). Observations on the Natural History of Stunting. In: Waterlow, J.C. ed., Linear Growth Retardation in Less Developed Countries. Nestlé Nutrition Workshop Series, Vol. 14. New York: Nestec Ltd., Vevey/Raven Press Ltd.

\section{Address for correspondence:}

Prof. Dr. Michael Hermanussen

Aschauhof 3

24340 Eckernförde - Altenhof

Germany

E-mail: michael.hermanussen@gmail.com

Dr. habil. Christiane Scheffler

Universität Potsdam

Institut für Biochemie und Biologie

FG Humanbiologie

Maulbeerallee 2a

14469 Potsdam

E-mail: christiane.scheffler@uni-potsdam.de 